\title{
ON THE GEOLOGICAL HISTORY OF THE BALTIC ICE LAKE
}

\section{Background}

In G. De Geer's monograph (1896) the whole of the pre-Ancylus Baltic Sea stage was called the Lateglacial Ice-Sea, although actually it was a fresh-water basin. It was supposed that this sea is represented by the highest shoreline, the «upper marine limit».

H. Munthe (1910) was the first to demonstrate the existence in the history of the Baltic after the last glaciation of an initial big ice-dammed fresh-water lake. This he did by comparing the highest shorelines on the west coast of Sweden with those on the east coast, i. e. by comparing the coast of the ocean with that of the Baltic. H. Munthe named the lake the Baltic Ice Lake. The drainage of the lake was then correlated with the recession of the ice margin from the Central Swedish endmoraines that resulted in the opening of the broad Närke Sound, allowing salt water to penetrate into the Baltic from the ocean. This drainage resulting in a partly saline Baltic was later on taken to mark the beginning of the Yoldia Sea.

It should be mentioned that the whole bulk of the material accumulated in recent years tends to refute the assumption about the penetration of the salty oceanic waters into the Baltic Sea in lateglacial time. All the arguments in favour of this conclusion, including the studies on easily soluble salts from water extracts, absorbed boron and gross content of the elements serving as the environmental indicators (Блажчишин, 1982) are not convincing enough. Instead of contributing to the input of salt water into the Baltic basin, the existing channels might have served as ways along which the surplus fresh water escaped from the basin (Гуделис, 1976). Slightly saline conditions existed after the drainage of the Baltic Ice Lake only near the Swedish coast but never in the open sea or in the Gulf of Finland.

In earlier works the highest raised beaches in the Baltic area had been taken to represent a lateglacial marine sea. It was supposed that there had been a connection with the ocean through Central Sweden, but it was also concluded that there might have been an early connection north-east to the White Sea via lakes Ladoga and Onega, as seen on the maps presented by W. Ramsay (1897) and J. Sederholm (1911).

In their early works on the history of the Baltic scientists were hampered by the lack of accurate contour maps which are available now. Therefore it was difficult for them to draw maps for the Baltic area showing the distribution of land and sea at various times of the recession of the last ice sheet. Also the measurements on the updoming of the earth's crust in the formerly glaciated area and the data for the block-wise tectonic movements in the region were insufficient.

According to the maps drawn by W. Ramsay (1927) there was no outlet of the Baltic to the White Sea. On later maps of the earlier phase of the Yoldia Sea formed shortly after the recession of the ice from the Salpausselkä moraines M. Sauramo $(1933,1934)$ drew the ice margin across the border similarly without an outlet of the Baltic to the White Sea. The history of the Baltic was therefore, according to these interpreta- 
tions, only regulated by outlets to the west, first through Central Sweden at the time of the Yoldia Sea, and later further south. However, E. Hyyppä (1936) in his studies of the raised beaches in north-eastern Finland, foremost in Kuusamo and Salla, connected the shorelines reaching altitudes of $250 \mathrm{~m}$ with the shorelines of the Baltic Ice Lake. According to Hyyppä's map of the Baltic Ice Lake it extended along the ice margin with narrow sounds up to north-eastern Finland, where it had an outlet east to the White Sea through Aapajärvi over a threshold at $211 \mathrm{~m}$, and earlier possibly also through the present Kitkajärvi and Paanajärvi basins. Later E. Hyyppä (1943) concluded that the Baltic Ice Lake was preceded by a marine stage in the Baltic which he named the Karelian Ice Sea and which was connected with the White Sea east of Hyrsylä but also further south along the Svir River between lakes Onega and Ladoga. M. Sauramo also adopted this Ice Sea into his succession of stages in the development of the Baltic. On his map M. Sauramo (1958, Fig. 133) called it the Lateglacial Yoldia Sea, showing a broad connection with the White Sea in north-eastern Finland, where its shoreline altitude exceeds $400 \mathrm{~m}$ at its highest (see also Donner, 1965). A later map by E. Hyyppä (1966) showed a more restricted Karelian Ice Sea, with the ice margin approximately along the second Salpausselkä moraine and the inner Karelian moraine further east but with a connection of the Baltic with the White Sea. At the time of the Baltic Ice Lake the ice margin followed the eastern border on Hyyppä's (1966) new map, but it differed in detail from the above-mentioned maps of the Baltic Ice Lake by extending this lake only as far north as to Kuhmo and with a separate ice-dammed lake in Kuusamo.

The correlation of the moraines in eastern Finland with those east of the Finnish border is not fully established. In Finland the first and second Salpausselkä moraines SsI and SsII form two distinct arcs, with their junctions in the Lahti area and west of Vääksy, respectively. The third Salpausselkä, SsIII, can only be traced in south-western Finland. In eastern Finland, in northern Karelia east of Joensuu, the first two Salpausselkä moraines are less distinct and are difficult to connect on morphological grounds alone.

The Karelian moraines on the eastern side of the Finnish border have been traced by A. Lukashov (1982) and I. Ekman (Экман, 1987). On Ekman's map the position of SsI is more easterly and closer to the White Sea, than on the map by Lukashov. Near the Finnish border both maps, however, area identical.

On H. Rainio's scheme $(1983,1985)$ the two main moraines in northern Karelia would represent SsII and the younger Pielisjärvi endmoraine, and these two would link up with the two Karelian endmoraines. The consequences of this correlation of the endmoraines on the connection of the shorelines have not been analysed.

In recent Soviet publications, compiled on the basis of complex investigations and a detailed survey of the topography, the penetration of saline oceanic waters from the White Sea to the Baltic is denied and therefore the boundary between the large local ice-dammed lakes and the Baltic Ice Lake has remained transitional and disputable.

\section{The extent of the Baltic Ice Lake and its shorelines}

Up to now there has been no generally accepted view as to the beginning of the Baltic Ice Lake applicable for the whole Baltic Sea basin. V. Gudelis (Гуделис, 1976) correlates the beginning of the Baltic Ice Lake with the release of the waters from the South-Baltic proglacial lake at Tyringe, South Sweden, which, according to E. Nilsson (1968), took place 
10,214 B. C. (about 12,200 B. P.). However, it did not result in a joining of all the isolated water basins in the Baltic proglacial lakes system (Квасов, 1976). According to D. Kvasov (Квасов, Краснов, 1965; Квасов, Раукас, 1970) the retreat of the ice margin from the northern part of the Pandivere Upland gave rise to the Baltic Ice Lake (during the «Estonian Billingen»), as a result of which all the basins west and east of this upland were joined. This was about 12,000 В. Р. (Раукас, Кессел, 1988).

The end of the Baltic Ice Lake, on the other hand, was already by H. Munthe (1910) connected with the drainage caused by the ice recession from Billingen in Central Sweden, which was dated by E. Nilsson (1968) at 8213 B. C. or 10,163 B. P. The drainage, also traced in Finland by W. Ramsay (1917), was later estimated to have been $28 \mathrm{~m}$ and to have taken place when the ice margin was inside SsII (Ramsay, 1927). Ramsay separated three shorelines of the Baltic Ice Lake below the shorelines of local ice-dammed lakes on the Karelian Isthmus and in Ingria (Ramsay, 1928) and Estonia (Ramsay, 1929). The difference in altitude between the highest and the lowest of the three shorelines varied from 10 to $15 \mathrm{~m}$. Ramsay named them BI, BII and BIII, of which BIII represented the water level during the final phase of the Baltic Ice Lake, before it fell as a result of the drainage of the lake. Unfortunately, quite frequently the heights presented in his works differ from those obtained through recent levellings (Пярна, 1960).

In Finland the work initiated by W. Ramsay was continued by M. Sauramo. In his scheme $(1934,1937,1940,1958)$, summarized by J. Donner $(1965,1969)$ and shown in Fig. 1, there was a first drainage of the Baltic Ice Lake down to sea level during the formation of SsI $(\mathrm{BI}-g)$, a second drainage to the level of the Yoldia Sea immediately after the formation of SsIl (BIII - YI) and a final drainage, again to the level of the Yoldia Sea, after the formation of SsIII (BVI - YI), the first drainage being about $25 \mathrm{~m}$ and the two later about $27-28 \mathrm{~m}$.

In later studies of the land/sea level changes in southern Finland it was concluded that there is no evidence for a rise of water level after the drainage of the Baltic Ice Lake immediately after the formation of SsII (Donner, 1964). The same conclusion was reached by M. Okko (1965). The shorelines BIV-BVI in Sauramo's scheme (1958) were therefore deleted. Another change to this scheme was the change in the age relationship between the BI and $g$ shorelines. It was concluded (Donner, 1969) that the high BI shoreline, during which a number of marginal deltas and sandurdeltas of SsI were formed was preceded by the low position of

Sauramo, 1934, 1937, 1950

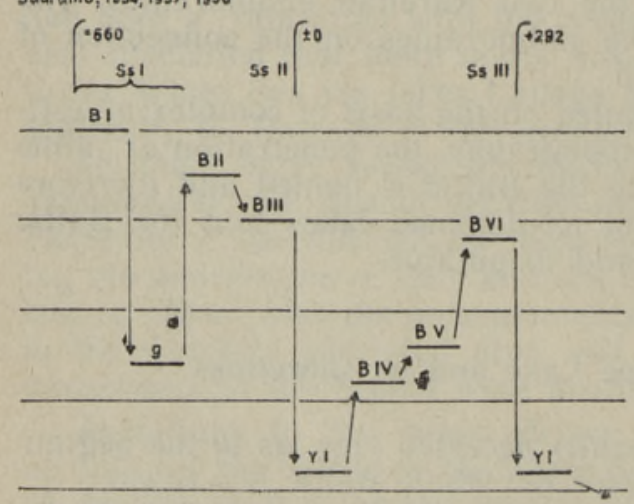

Donner, 1969

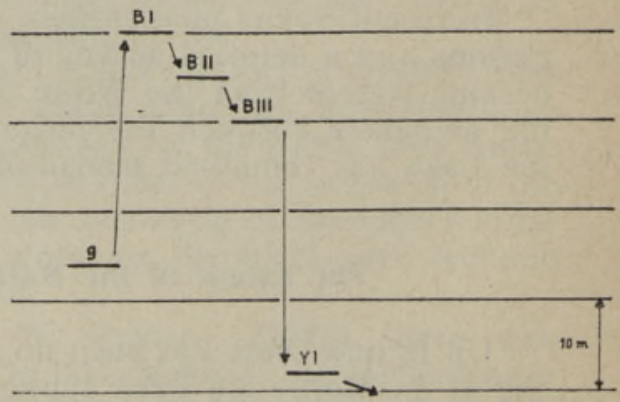

Fig. 1. Land/sea level changes during the formation of the Salpausselkä endmoraines according to $M$. Sauramo and J. Donner. Years refer to varve chronology for southern Finland established by M. Sauramo (after Donner, 1969). 
water level represented by the $g$ shoreline (Donner, 1978). According to the new scheme for Finland (Fig. 1) there was thus only one major damming of the waters of the Baltic Ice Lake during the formation of the Salpausselkä moraines before the final drainage.

In the Leningrad region the history of the development of the Baltic Ice Lake and local glacial lakes was studied in detail by S. Yakovlev (Яковлев, 1926) and K. Markov (Марков, 1931). S. Yakovlev followed on the results of G. De Geer, whereas K. Markov's studies were based on the conclusions of W. Ramsay. Following on the presentation of different viewpoints in Soviet publications in the 1930s, a compromise was reached and a palaeogeographic scheme elaborated according to which in the Older Dryas there existed the I Baltic Ice Lake with its level at an altitude of $36-38 \mathrm{~m}$ in the Leningrad region. In the Allerød a deep regression took place during which salt water penetrated into the Baltic depression and the I Yoldia Sea was formed. It was supposed that in the Younger Dryas a new transgression took place and that the II Baltic Ice Lake came into being. In the Leningrad region its level was at an altitude of $28 \mathrm{~m}$.

However, already at the end of the 1930s there arose some doubt as to the validity of this scheme. In the vicinity of Leningrad S. Lapin (Лапин, 1939) studied the Ust-Tosno peatbog which had developed steadily since the beginning of the Allerød. The base of the peatbog lies at an absolute height of $10 \mathrm{~m}$. However, this circumstance cannot be associated with the existence of large water basins with high levels in this area (Квасов, Раукас, 1970).

In recent years the age of the Allerød regression has been a matter of dispute as well. The corresponding conclusion was drawn already by K. Markov (Марков, 1931) on the basis of studies of the buried peat of Allerød age at Gorelovo. Recent palynological studies of this section (Ceребрянный, Пуннинг, 1969) show that here the buried peat could not have formed until the Preboreal, and, hence, cannot serve as a basis for studying the postglacial history of the Baltic Sea.

In Estonia two levels have been established above the reference level $\mathrm{B}_{I I I}$ and three levels below it for the Baltic Ice Lake (Пярна, 1960). The highest of these levels $(68-70 \mathrm{~m})$ is $\mathrm{B}_{\mathrm{I}}$ on the northwestern slope of the Pandivere Upland. A bit lower $(2-4 \mathrm{~m})$ there remains the level $\mathrm{B}_{\mathrm{II}}$. The level $\mathrm{B}_{\mathrm{IV}}$ lies approximately $10 \mathrm{~m}$ below the reference level $\mathrm{B}_{\mathrm{III}}$. Still lower is the level which $\mathrm{K}$. Pärna has marked with the index C (18 m below $\mathrm{B}_{111}$ ). According to K. Pärna (Пярна, 1960, 1962) there was a deep regression prior to the level $B_{1}$ whose traces are observable on Naissaar Island in the form of fluvioglacial deltas near the present-day sea level. After the Billingen outflow near Pärnu the regression was about 25$30 \mathrm{~m}$ (Talviste, 1988). The level $\mathrm{B}_{\text {III }}$ can be correlated with the following levels (Table 1): C - by A. Tammekann (1926) in the northeastern part

Table 1

A preliminary correlation scheme of the Baltic Ice Lake stages in Eastern Baltic

\begin{tabular}{|c|c|c|c|c|}
\hline $\begin{array}{l}\text { SW Finland } \\
\text { after } \\
\text { J. Donner }\end{array}$ & $\begin{array}{c}\text { Leningrad region } \\
\text { after K. Markov, } \\
\text { O. Znamenskaya } \\
\text { inter alios }\end{array}$ & $\begin{array}{c}\text { Estonia } \\
\text { after K. Pärna, } \\
\text { H. Kessel, } \\
\text { A. Raukas } \\
\text { inter alios }\end{array}$ & $\begin{array}{c}\text { Latvia } \\
\text { after } \\
\text { E. Grinbergs }\end{array}$ & $\begin{array}{l}\text { Lithuania } \\
\text { after } \\
\text { V. Gudelis }\end{array}$ \\
\hline $\begin{array}{c}g \\
\mathrm{~B}_{\mathrm{I}, \mathrm{II}}^{\mathrm{g}} \\
\mathrm{B}_{\mathrm{III}}\end{array}$ & $\begin{array}{c}\mathrm{G}_{\mathrm{I}}-\mathrm{G}_{\mathrm{II}} \\
\mathrm{G}_{\mathrm{III}} \\
\mathrm{G}_{\mathrm{IV}}\end{array}$ & $\begin{array}{c}\mathrm{G}_{1}-\mathrm{G}_{\mathrm{III}} \\
\mathrm{B}_{\mathrm{I}}, \mathrm{II} \\
\mathrm{B}_{\mathrm{III}} \\
\mathrm{B}_{\mathrm{IV}, \mathrm{V}}\end{array}$ & $\begin{array}{l}\mathrm{Bgl}_{\mathrm{I}} \\
\mathrm{Bgl}_{\mathrm{II}} \\
\mathrm{Bgl}_{\mathrm{III} \mathrm{a}} \\
\mathrm{Bgl}_{\mathrm{IIb}} \\
\mathrm{Bgl}_{\mathrm{IIIC}}\end{array}$ & $\begin{array}{l}\mathrm{BG}_{\mathrm{I}} \\
\mathrm{BG}_{\mathrm{II}}\end{array}$ \\
\hline
\end{tabular}


of the Estonian territory, $\mathrm{G}_{1 \mathrm{~V}}$ by K. Markov (Марков, 1931) in the northwestern part of the Leningrad Region, $B_{V}$ by M. Sauramo (1940) and $\mathrm{B}_{\text {III }}$ by M. Sauramo (1938) and J. Donner (1969) in South Finland, $\mathrm{B}_{\text {II }+ \text { III }}$ by E. Lõokene (1961) on the northwestern slope of the Sakala Upland, Bgl $\mathrm{H}_{11 \mathrm{a}}$ by E. Grinbergs (Гринбергс, 1957) in Latvia, $\mathrm{B}_{3}$ by K. Pärna (Пярна, 1960), B B

In Latvia the shorelines of the Baltic Ice Lake are represented by stages $\mathrm{Bgl}_{1}, \mathrm{Bg}_{I I}$ and $\mathrm{Bg}_{I I I}$ ( $\mathrm{Bg}_{\text {IIIa }}, \mathrm{Bgl}_{\text {IIIIb }}$ and $\mathrm{Bgl}_{\text {IIIc }}$ phases). The age of the transgressive $\mathrm{Bgl}_{1}$ stage has not been precisely determined. A rapid transgression of the basin followed at the end of the stage (Veinbergs, 1980). The $\mathrm{Bgl}_{\mathrm{II}}$ stage dates back to the Allerød and was completed in the Younger Dryas. It had a transgressive character (Гринбергс, 1957). The date of the regressive basin of the $\mathrm{Bgl}_{\mathrm{III}}$ stage is in close correlation with the Younger Dryas. The shoreline of the $\mathrm{Bgl}_{\text {IIrb }}$ phase is best defined along the Latvian coast as a whole and was taken by E. Grinbergs as a basis for the diagrams of the Baltic Ice Lake shoreline in Latvia.

In Lithuania there are two Baltic Ice Lake shorelines (BGI and BGII). BGII represents most likely the oldest shore formation of the Baltic basin on the Lithuanian coast and lies at an absolute height of $11-10 \mathrm{~m}$ to the south of Palanga (Gudelis, 1980). The BGI terrace is cut off by the Litorina cliff. The beach ridge BGII was formed by a rapid transgression of the Baltic Ice Lake in the Younger Dryas (Gudelis, 1980), and can be correlated with the BIII level in the northern Baltic. BGI belongs to the Older Dryas and was separated from the BGII stage with the deep Allerød regression. According to V. Gudelis (Гуделис, 1976) the stage of the Baltic Ice Lake lasted from c. 12,200 up to 10,2000 years B. P.

In the Southern Baltic (Poland, GDR, FRG) the Pleistocene shorelines are not detected and they lie under the contemporary sea level, in the Gdansk Bay at a depth of about 20-40 m (Гуделис, 1976). In Denmark Late Weichselian shore marks are known from Bornholm, at altitudes of up to $21 \mathrm{~m}$, but they were probably formed in local ice lakes. The Baltic Ice Lake beaches are not known here, neither above nor below sea level (Krog, 1980). The complicated shore level history of the Late Weichselian in Sweden has been discussed in many publications (see Freden, 1980; et al.).

The palaeogeographical maps showing the extent of the Baltic Ice Lake before its drainage (Fig. 2), broadly contemporaneous with shoreline BIII, have not significantly been altered from that presented by $M$. Sauramo (1958). The isobases drawn for the BIII shoreline show that the gradient was greater in southern Finland than south of the Gulf of Finland. The gradient has been estimated at $6.9 \times 10^{-4}$ in the former area and $3.8 \times 10^{-4}$ in Estonia (Donner, 1970), and a difference in the gradients of younger shorelines between the more central area of uplift as compared with the marginal area has also been observed in the Lake Ladoga area (Saarnisto, Siiriäinen, 1970).

Further, the direction of the tilt and the gradients have been observed to differ between different phases of the Baltic Ice Lake development. Thus, according to K. Pärna (Пярна, 1960, 1962) in the Estonian territory the direction of the tilt of the Earth's crust is $326^{\circ}$ and the gradient in the north-western part of the territory for BII is $46 \mathrm{~cm} / \mathrm{km}$, BIII $45 \mathrm{~cm} / \mathrm{km}$, BIV $44 \mathrm{~cm} / \mathrm{km}$ and for BV about $42 \mathrm{~cm} / \mathrm{km}$. The directions of the greatest tilt of the levels of local glacial lakes $\mathrm{A} 1$ and $\mathrm{A} 2$ differ from the corresponding directions of the Baltic Ice Lake levels and are about $335^{\circ}$ $\left( \pm 5^{\circ}\right)$; the gradients are as follows: for level Al between the isobases of Voose and Alatskivi about $40 \mathrm{~cm} / \mathrm{km}$, level A2 in the proximal part about $34 \mathrm{~cm} / \mathrm{km}$ and in the central part (between the isobases of Vahastu and Mustjōe) $30-31 \mathrm{~cm} / \mathrm{km}$. 


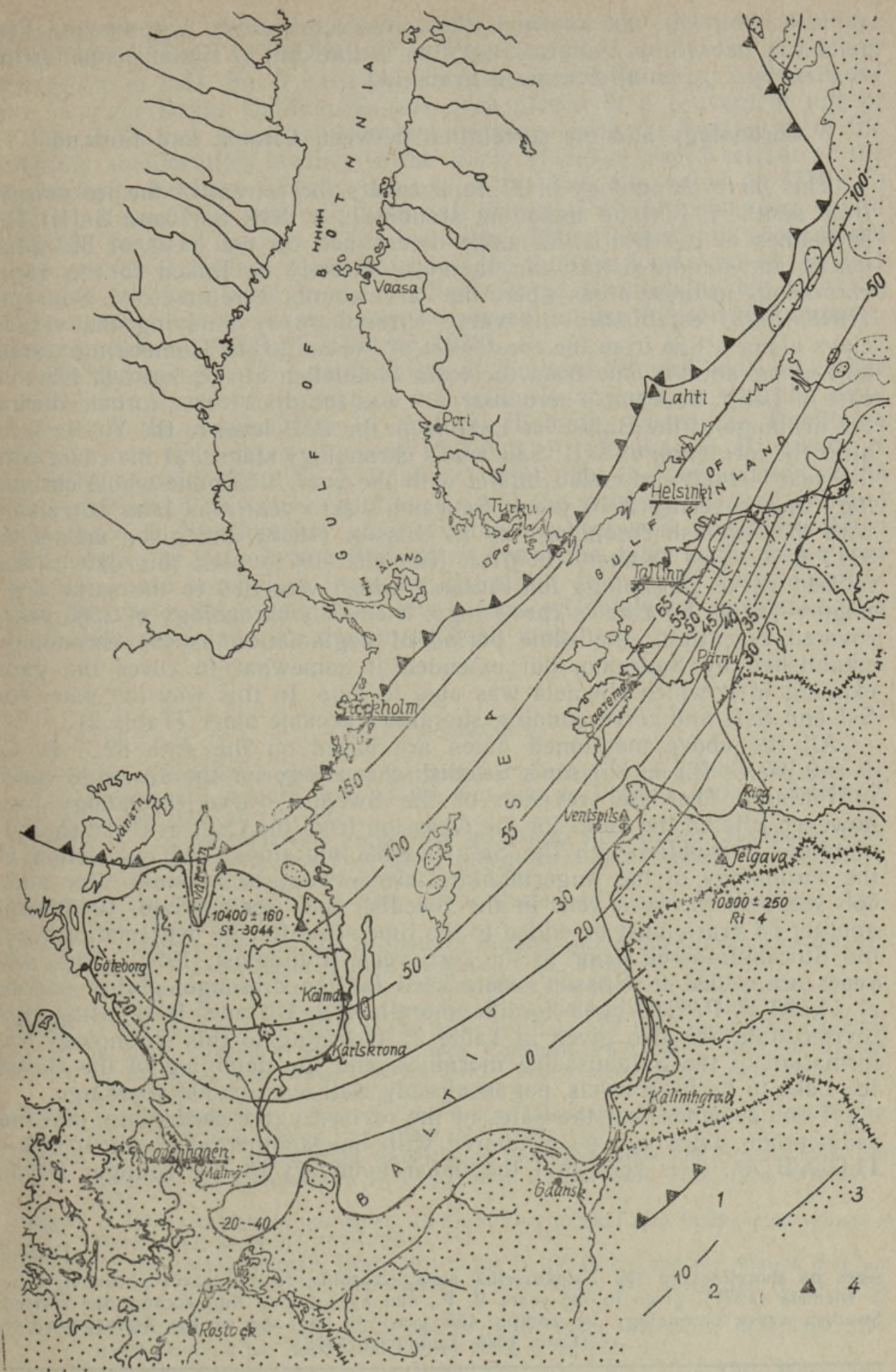

Fig. 2. Map of the Baltic Ice Lake during the formation of the Salpausselkä endmoraines about 10,800 years ago (shoreline BIII): 1 - standstill of glaciers, 2 - isobases of the crustal movements, 3 - the coast line of the Baltic Ice Lake, 4 - the location of the most important sites.

(Compiled by Helgi Kessel on the basis of various published sources.) 
It is, however, not known if the difference between Estonia and Finland was caused by a sharp hinge-line in the Gulf of Finland and further east or by a gradual change in gradient.

\section{Chronology and the correlation between Estonia and Finland}

The varve chronology of Finland covers the retreat of the ice margin from southern Finland including standstills at SsI, SsII and SsIII. The shorelines of the Baltic Ice Lake determined on the basis of marginal deltas and sandur-deltas can therefore directly be linked to the varve chronology in those areas where the varve counts were made. M. Sauramo $(1918,1923)$ established his varve chronology by studying the varved clays along a line from the coast west of Porvoo to the Hämeenlinna area, and along another line from the town of Loviisa at the coast of Nastola east of Lahti. Sauramo's zero year \pm 0 was the thick varve formed during the drainage of the Baltic Ice Lake from the BIII level to the Yoldia level after the formation of SsII. Sauramo's chronology started at the coast with the year -1480 and ended inland with the year +730 , the whole chronology thus covering 2210 years. Sauramo's zero year was later correlated with the Swedish chronology by E. Nilsson (1968) and given an age of 8213 B. C. (see Donner, 1969). J. Niemelä (1971) used this date in his revised varve chronology for Finland, which was tied to the same drainage varve as Sauramo's chronology. Niemelä's chronology of 2500 years covered essentially the same period of deglaciation as the chronology established by Sauramo, but extended it somewhat to cover the gaps existing in it which Niemelä was able to date. In this way the dates for SsI and SsII and corresponding shorelines became older (Table 2).

All the above mentioned dates are based on the date $8213 \mathrm{~B}$. C. $(=10,163$ B. P.) in Nilsson's Swedish chronology for the drainage varve in Finland. The later revision of the Swedish varve chronology has, however, altered the dates for the recession from the Central Swedish endmoraines correlated with the Salpausselkä moraines. The connection of the chronology of the Angermanland river valley to calendar time adds 365 years to the zero year in the Swedish time scale (Cato, 1985) and another 65 years must be added to the time scale for the deglaciation from the Stockholm area prior to the zero year (Lundqvist, 1986). Thus 430 years are added to Nilsson's date used for the drainage, giving a date at $10,593 \mathrm{~B}$. P. The ages for the shorelines $g$, BI and BIII using this revised date are also given in Table 2. According to this chronology the formation of the Salpausselkä moraines, and the damming of the Baltic Ice Lake to its high levels, began already well over 11,000 years ago.

If one assumes that the dates of the revised varve chronology and the radiocarbon dates can be compared with one another at about $10,000-$ 11,000 B. P., it is seen that the upper boundary of the Younger Dryas

Table 2

Ages of shorelines in the Salpausselkä zone according to the varve chronology by J. Niemelä (1971), given in the years B. P., and ages taking into account the revised Swedish varve chronology by adding 450 years to the age of the drainage varve (Cato, 1985; Lundqvist, 1986)

\begin{tabular}{c|c|c}
\hline Shorelines & Previous ages & Revised ages \\
\hline$g$ & $11,200-10,950$ & $11,650-11,380$ \\
BI & $10,850-(10,650)$ & $11,280-(11,080)$ \\
BIII & $10,450-10,163$ & $10,880-10,593$ \\
& $(=$ drainage varve $)$ & $(=$ drainage varve $)$
\end{tabular}


Chronozone by J. Mangerud et al. (1974) is about 500-600 years younger than the drainage of the Baltic Ice Lake and the withdrawal of the ice margin from SsII. But it must be remembered that the upper boundary for the Younger Dryas Chronozone has been placed at a convenient age of 10,000 B. P., not necessarily contemporaneous with the beginning of the climatic amelioration leading to the Early Holocene rapid retreat of the ice margin. Further, already the use of the half life value of $5730 \pm 40$ years instead of the generally used half life value of $5570 \pm 30$ years would add 300 years to the age of the boundary. Thus, taking into account the inaccuracies of dating, it can be concluded that the formation of the SsII moraine can be placed in the Younger Dryas Chronozone but that the SsI moraine can at least partly be placed in the Allerød Chronozone, formed before 11,000 B. P. (Donner, 1978).

The chronology of the deglaciation of southern Finland, with an earlier retreat than formerly assumed, is not seriously at variance with the chronology of the deglaciation in northern Estonia, where the Pandivere moraine has been dated at about 12,000 B. P. (Raukas et al., 1969). It is likely, as pointed out by A. Raukas (1986), that the deglaciation of the Gulf of Finland was very rapid because of the presence of dead ice, and that there is therefore no great discrepancy between the deglaciation chronologies in Estonia and Finland. Many of the dates in the latter area are, as should be obvious from the discussion above, still very tentative. And the varve dates cannot by any means yet safely be correlated with the radiocarbon dates for the period dealt with here.

\section{RFERENCES}

Cato, I. The definitive connection of the Swedish geochronological time scale with the present, and the new data of the zero year in Döviken, northern Sweden // Boreas, 1985, 14, 117-122.

De Geer, G. Om Skandinaviens geografiska utveckling efter istiden. Stockholm, 1896.

Donner, J. The Late-glacial and Post-glacial emergence of south-western Finland // Soc. Sci. Fennica. Comment. Phys.-Math., 1964, 30.

Donner, J. The Quaternary of Finland // The Quaternary, 1 (ed. K. Rankama). London, $1965,199-272$.

Donner, J. Land/sea level changes in southern Finland during the formation of the Salpausselkä endmoraines // Bull. Geol. Soc. Finl., 1969, 41, 135-150.

Donner, J. Deformed Late Weichselian and Flandrian shore-lines in south-eastern Fennoscandia // Soc. Sci. Fennica. Comment. Phys.-Math., 1970, 40, 191-198.

Donner, $J$. The dating of the levels of the Baltic Ice Lake and the Salpausselkä moraines in South Finland // Soc. Sci. Fennica. Comment. Phys.-Math., 1978, 48, 11-38.

Freden, C. The Quaternary history of the Baltic. The western part // Acta Univ. Ups. Symp. Univ. Ups. Ann. Quing. Cel., 1980, N 1, 127-146.

Gudelis, V. The Quaternary history of the Baltic. Lithuania // Acta Univ. Ups. Symp. Univ. Ups. Ann. Quing. Cel., 1980, N 1, 159-173.

Hyyppä, E. Ober die spätquartäre Entwicklung Nord-Finnlands mit Ergänzungen zur Kenntnis des spätglazialen Klimas // Bull. Comm. Géol. Finl., 1936, 115, 401465.

Нyуррӓ, E. Itämeren historia uusimpien Itä-Karjalassa suoritettujen tutkimusten valossa / Terra, 1943, 55, N 3/4, 122-127.

Hyуррӓ, E. The Late-Quaternary land uplift in the Baltic sphere and the relation diagram of the raised and tilted shore levels // Ann. Acad. Sci. Fenn. Ser. A III, 1966, $90,153-168$.

Kessel, H., Raukas, A. The Quaternary history of the Baltic. Estonia // Acta Univ. Ups. Symp. Univ. Ups. Ann. Quing. Cel., 1980, N 1, 127-146.

Krog, $H$. The Quaternary history of the Baltic. Denmark // Acta Univ. Ups. Symp. Univ. Ups. Ann. Quing. Cel., 1980, N 1, 207-217.

Lukashov, A. D. Karelia. Guidebook for Excursions A-4, C-4. INQUA XI Congress. Moscow, 1982.

Lundqvist, J. Late Weichselian glaciation and deglaciation in Scandinavia // Quat. Sci. Rev., 1986, N 5, 269-292.

Lõokene, E. Mandrijää servamoodustistest, fluvioglatsiaalsetest setetest ja mandrijää taandumisest Sakala kōrgustiku pōhja- ja keskosas // Geoloogiline kogumik (ENSV TA LUS). Tartu, 1961, 84-105. 
Mangerud, J., Andersen, S. T., Berglund, B. E., Donner, J. J. Quaternary stratigraphy of Norden, a proposal for terminology and classification // Boreas, 1974, N 3, $109-128$.

Munthe, H. Studies in the Late-Quaternary history of southern Sweden // Geol. Fören. Stockh. Förh., 1910, N 32, 1197-1293.

Niemelä, J. Die quartäre Stratigraphie von Tonablagerungen und der Rückzug des Inlandeises zwischen Helsinki und Hämeenlinna in Südfinnland // Geol. Surv. Finl. Bull., 1971, 253,

Nilsson, E. Södra Sveriges senkvartära historia // K. Sv. Vet.-Akad. Handl., 1968, 4, N 12 (1).

Okko, M. M. Sauramo's Baltic Ice Lake BIV-BV-BVI, a re-evaluation // Ann. Acad. Sci. Fenn. Ser. AIII, 1965, N 84.

Rainio, H. The Tuupovaara end moraine in Norih Karelia, Eastern Finland // Bull. Geol. Soc. Finl., 1983, 55, N 1, 67-76.

Rainio, $H$. Pohjois-Karjalan Salpausselkien aikaiset reunamuodostumajaksot tarvitsevat nimet // Geologi, 1985, 37, N 3, 48-50.

Ramsay, W. Finlands geologiska utveckling frân istiderna intill văra dagar. Helsingfors, 1987.

Ramsay, W. De s.k. marina gränserna i södra Finland // Fennia, 1917, 40, N 7.

Ramsay, W. Silmäys Suomen syntyyn. Kutsu maisterin ja tohtorin-promotsoneihin. Helsinki, $1927,5-30$.

Ramsay, W. Eisgestaute Seen und rezession des Inlandeises in Südkarelien und in Newatal // Fennia, 1928, 50, N 5.

Ramsay, W. Niveauverschiebungen, Eisgestaute Seen und Rezession des Inlandeises in Estland // Fennia, 1929, 52, N 2.

$\checkmark$ Raukas, A. Deglaciation of the Gulf of Finland and adjoining areas // Bull. Geol. Soc. Finl., 1986, 58, N 2, 21-33.

Raukas, A., Punning, J.-M., Rähni, E. Millal taandus Eestist mandrijää? // Eesti Loodus, 1969, N 7, 396-401.

Saarnisto, M., Siiriäinen, A. Laatokan transgressioraja // Suomen Museo, 1970, 10-22.

Sauramo, M. Geochronologische Studien über spätglaziale Zeit in Südfinnland // Fennia, $1918,41, \mathrm{~N} 1$.

Sauramo, M. Studies on the Quaternary varve sediments in southern Finland // Bull. Comm. Géol. Finl., 1923, 60; Fennia, 1923, 44, N 1.

Sauramo, M. Yoldiameri entisten ja nykyisten tutkimusten valossa // Terra, 1933, 45, N 1, 1-14.

Sauramo, M. Zur spätquartären Geschichte der Ostsee // C. R. Soc. Géol. Finlande, 1934, 8; Bull. Comm. Géol. Finl., 1938, 104, 28-87.

Sauramo, M. Das System der spätglazialen Strandlinien im südlichen Finnland // Soc. Sci. Fennica. Comment. Phys.-Math., 1937, 9, N 10.

Sauramo, M. Suomen luonnon kehitys jääkaudesta nykyaikaan. Helsinki, 1940.

Sauramo, M. Die Geschichte der Ostsee // Ann. Acad. Sci. Fenn. Ser. A III, 1958, N 51.

Sederholm, J. J. VI. Extension de la mer vers la fin de l'époque glaciaire (Atlas de Finlande, Carte N:o 6a) // Fennia, 1911, 30, 88-106.

- Talviste, P, Pärnu ümbruse geoloogilise arengu mudel // Eesti geotehnika konverentsi teesid. Tallinn, 1988, 49-50.

Tammekann, A. Die Oberflächengestellung des Nordestländischen Küstentafellandes // Acta Univ. Tartu, 1926, A9, N 7, 1-152.

Veinbergs, I. The Quaternary history of the Baltic. Latvia // Acta Univ. Ups. Symp. Univ. Ups. Ann. Quing. Cel., 1980, N 1, 147-157.

Блажчишин А. И. О позднеледниковом проникновении соленых вод в Балтийскую котловину // Peribalticum. Wrocław, 1982, N 2, 213-217.

Гринберес Э. Ф. Позднеледниковая и послеледниковая история побережья Латвийской ССР. Рига, 1957.

Гуделис В. К. История развития Балтийского моря // Геология Балтийского моря. Вильнюс, 1976, 95-116.

Квасов Д. Д. Позднечетвертичная история крупных озер и внутренних морей Восточной Европы. Л., 1976.

Квасов Д. Д., Краснов И. И. Основные проблемы истории приледниковых озер северозапада Европейской части СССР // Мат-лы к симп. по истории озер северозапада. Л., 1965.

Квасов Д. Д., Раукас А. В. О позднеледниковой истории Финского залива // Изв. Всес. геогр. о-ва, $1970,5,432-438$.

Лапин C. С. Четвертичные отложения района нижнего течения р. Тосны // Уч. зап. Ленингр. ун-та, $1939,25$.

Марков K. K. Развитие рельефа северо-западной части Ленинградской области // Тр. Гл. геологоразвед. управл. ВСНХ СССР. М.-Л., 1931, 117.

Пярна К. Геология Балтийского приледникового озера на территории Эстонии // Тр. Ин-та геологии АН ЭССР, 1960, 5, 269-278.

Пярна К. О геологии Балтийского прнледникового озера и крупных местных приледниковых озер на территории Эстонии. Автореф. канд. дис. Таллинн, 1962. 
( Раукас А. В., Кессел Х. Я. Основные проблемы палеогеографии Балтийского моря //
Геол. ж., 1988, № 1, 91-98.

Серебрянный Л. Р., Пуннина Я.-М. К. Результаты радиометрического и палинологического изучения погребенного торфяника в районе Горелово-Койерово под Ленинградом // Голоцен. М., 1969, 101-110.

Экман И. М. Четвертичная система // Геология Карелин. Л., 1987, 79-93.

Яковлев С. А. Наносы и рельеф Ленинграда и его окрестностей. Л., 1926.

\section{University of Helsinki}

Academy of Sciences of the Estonian SSR, Institute of Geology

Received

Feb. 6, 1989

\section{J. DONNER, A. RAUKAS}

\section{BALTI PAISJARVE ARENGUST}

Balti paisjärv on Läänemere esimene arenguetapp. Järve alguseks peetakse mandrijää taandumist Pandivere kõrgustikult umbes 12000 aastat tagasi, löpuks aga järve veepinna järsku alanemist Billingeni läbimurde tagajärjel 8213 aastat e.m.a. Artiklis on kirjeldatud Salpausselkä mandrijää servamoodustiste kujunemist ja selle seost järve veetaseme muutusega. Esitatud on ka Balti paisjärve tasemete rööbistus Ida-Baltikumis ja paisjärve juhttasemete täpsustatud vanus.

\section{П. ДОННЕР, А. РАУКАС}

\section{К ИСТОРИИ БАЛТИИСКОГО ЛЕДНИКОВОГО ОЗЕРА}

Балтийское ледниковое озеро (БЛО) является первой стадией развития Балтийского моря. Впервые она была выделена шведом Х. Мунтхе в 1910 году. Нижнюю хронологическую границу БЛО разные исследователи проводят по-разному. Вслед за Д. Квасовым авторы началом зарождения БЛО счнтают момент соединения ЮжноБалтийского приледникового озера с остатками озера Рамсея, что произошло около 12000 лет назад после отступания ледника с Пандивереской возвышенности в Северной Эстонии. Завершение БЛО большинство авторов связывают с резким спуском озера, когда фронт ледника отступил от северных склонов горы Биллинген в Средней Швеции, что Э. Нильсоном (Nilsson, 1970) датируется 8213 лет до н. э. Классическим объектом изучения истории развития БЛО является дуга краевых ледниковых образований Сальпаусселькя в Южной Финляндин. В работе дается хронология формирования трех гряд Сальпаусселькя и их связь с изменениями уровня БЛО, а также корреляция уровней
БЛО в Восточной Прибалтике. Авторы исходят из предположения, что в позднеледниковое время Балтийское море не имело соединения с океаном через Ладогу, Онегу и Белое море, а соединение с океаном с запада было весьма ограниченным. 